\title{
The Enlightenment of German FH Education to the Cultivation of Applied Talents for Our Country's Local Colleges and Universities
}

\author{
Guan Xiang-feng ${ }^{1, a}$, Liu Jin-ling ${ }^{2, b}$ \\ ${ }^{1}$ Faculty of Foreign Languages, Huaiyin Institute of Technology, \\ Huaian, 223003, China \\ ${ }^{2}$ Faculty of Computer Science Engineering, Huaiyin Institute of Technology, \\ Huaian, 223003, China \\ aemail: guanxiangfeng01@126.com, bemail:liujinlingg@126.com
}

Keywords: German FH; local colleges and universities; applied talents; cultivate

\begin{abstract}
German universities of applied science and technology (FH is the abbreviated form to Fachhochschule) are the new kind of institutions of higher learning to cultivate advanced applied talents in Germany. This essay first introduces the teaching concept, the training goal, the curriculum system, talents evaluation mode, the construction of teachers' team and internal teaching methods of $\mathrm{FH}$ applied talents training program then directs at the existing problems of newly established colleges and universities in cultivating applied talents, finally puts forward several proposals to the cultivation of applied talents in our country's local colleges and universities.
\end{abstract}

\section{Introduction}

The cultivation of applied talents focuses on the cultivation of practical ability, the cultivation of modern technology utilizers, executors and implementers. Local colleges and universities are closely linked with the local economic and social development, which have unique advantages and play an important role in the cultivation of applied talents. One of the successful experiences for the economic development of developed countries is that the education departments constantly send advanced applied talents to the society. Hence, the cultivation of applied talents plays an irreplaceable important role. As a successful innovating mode of the cultivation of advanced applied talents, the establishment of the universities of applied science in the late 1960s and early 1970s in Germany, is regarded as the" secret weapon "for post-war Germany once more to become one of the world's industrial powers and economic powers." [1], Therefore, it is very necessary to fully understand and study German advanced applied talents training features, introduce German advanced education concept and practice mode, orient and form talent training mode especially for the newly-established colleges and universities by drawing on the successful experience of other countries.

\section{Training mode of FH talents}

As a new kind of universities of applied science and technology which are different from the general academic universities, German FH have formed a complete and effective implementation system after decades of development[2], whose talents' training characterizes for its applied and practical features and has received the society's universal welcome.

Training target

The guidance of FH training target is students' needs of future employment posts, which proposes "the universities of applied science and technology should cultivate their graduates more close to the customers" [3] .According to the principle of close to the customers, FH always study economic and social development and changes, grasp the enterprises' actual demands, and determine the professional training objectives from the needs of future jobs for talents. Compared with the traditional comprehensive universities, applied science and technology universities are to cultivate 
talents with strong major knowledge, practical application of advanced skills, whom German economic circles and the business management see as the talents who combine theoretical knowledge with practical application of technology, namely" professional talents between theory and practice" [4].

Arrangement for practice teaching

FH closely stick to their applied talents training target, lay particular stress on professional knowledge closely related to practice, methods and skills, and also emphasize the application of knowledge and methods in the practical work [5], which have perfected the construction of curriculum system.

In order to develop the students' practical application ability, they guarantee an adequate proportion of practice teaching in the curriculum arrangement. FH classroom teaching can be divided into theory and problem-solving classes, teachers attach great importance to the theoretical basis and practical application ability training, whose teaching hours ratio is usually 2:1 [6]. In the theory classroom teaching, teachers adopt ways of discussion with students, which contain questions, practice, examples and experimental demonstration and so on in smaller student groups. This teaching method, on the one hand, has ensured the communication between teachers and students in the teaching process, on the other hand, has ensured many kinds of teaching means and methods to carry out effectively, such as case teaching, research teaching, combination of classroom and laboratory teaching, etc. The starting point of theory teaching is not systematic knowledge of courses, but knowledge closely related with practice, which focuses on how to apply scientific knowledge and methods to real production practice, whose teaching content is based on the development of the knowledge of courses and change of real application, which will be added and revised constantly. In the teaching activities of $\mathrm{FH}$, practice teaching is one of the very important parts, including experimental teaching, practice semester, project design teaching and academic travel. Practice semester teaching activities of FH is the most distinctive part, which is carried out in the enterprises or other work fields related outside universities, the purpose of which is to improve students' abilities to solve real problems, deepen their understanding of the working posts by the use of scientific knowledge and methods through practice semester.

Graduation and employment

German FH adopts the management method of easy enrollment and difficult graduation, the rate of students who can't graduate is generally 30\% [7]. Students must pass examinations of all courses, the number of examinations for each course is three times at most (including a make-up exam and an oral defense). The rate of students who can't graduate is $45 \%$ - $50 \%$ for many engineering specialties . Although high rate of students who can't graduate and the waste of limited teaching resources have created a lot of disputes in recent years, these measures have effectively guaranteed the teaching quality. Therefore, compared with the graduates of comprehensive universities and other kinds of universities, FH graduates have more practical knowledge, can quickly adapt to work and solve various kinds of technical problems in enterprises. Hence, they are very popular in enterprises. As for the rate of unemployment for $\mathrm{FH}$ graduates, it is $2.6 \%$, much less than $3.9 \%$ of the comprehensive university graduates [8].

Evaluating methods

The exam outline of FH embodies its training plan and teaching contents. Each specialty training plan is not only the basis of each specialty department implementation teaching activities, but also students' learning guidance. Exam outline stipulates relevant specialty conventional learning time, the conditions for students to participate in the graduation exams, the recognition of learning and examination results, the time of writing graduation theses, examination requirements, examination procedures and the examination courses, etc. As for the evaluation methods for FH students, there are methods for exams, appraisals, graduation design defenses, etc, whose characteristics is emphasize the evaluation of students' practical abilities. During teaching process, students may be absent from lectures, don't complete the homework, but they must complete their experiments and pass their exams. Practice is one of the main teaching forms for the universities of applied science and technology (FH), so the evaluation in the process of practice is also very important. Because the 
evaluation of this period focuses on practical ability, it depends mainly on the appraisals of enterprise technicians or workers on shift and enterprise certificates for their performances in practice. Only after students have accomplished all courses specified in the teaching plan, can they begin their graduation designs. They can either do them in the domestic or foreign enterprises or the university labs, and finally pass the defenses by the teachers and technicians in charge of their practice in the enterprises. Graduation examination includes the written exam, oral exam, and degree thesis of practical use. The time stipulated for degree thesis is more than 3 months; each student must complete it mainly in combination with the actual tasks in the practice enterprise. The rate of combination between graduation thesis for $\mathrm{FH}$ graduates and the enterprise practice is quite high. According to statistics, projects of graduation thesis for many engineering specialties come from enterprises, and they tend to complete $60 \% \sim 70 \%$ of their thesis in the enterprises [9].

\section{The characteristics of training mode for FH applied talents}

As the important composition of German higher education system, FH connotation and essence is to face the practice and the application for undergraduate technical education. The characteristics of FH schooling system, specialty arrangements, teaching reform closely in combination with enterprises shows its strong flexibility, practicability and vitality. Its unique characteristics are as follows:

Establish its position by legislation

The reason why German FH have been developing so rapidly and have cultivated such large quantities of higher technical talents is that German government attaches great importance to the higher technical education and strict legislations to ensure the effective implementation. The position of German universities of applied science and technology (FH), the direction of cultivation and its implementing measures are recognized by laws of federal government and each state government and they have got strong support both from governments of all levels, society and enterprises [10].

The cooperation between universities and enterprises to cultivate applied talents

The most important security for FH great success lies in their close effective cooperation with enterprises. On the one hand, it introduces the latest production technical theory and knowledge to teaching. On the other hand, it enhances the "natural contact" between FH, society and enterprises.

In order to guarantee the students' practical ability training, FH requirements for teachers' practical ability are very high, which demand teachers have at least 5 years of practical work experience in technology research and development. Many technicians in enterprises act as part-time teachers in the universities of applied science and technology, and at the same time, some enterprises have set up funds for professors to pay their salaries or subsidies.

Establish a perfect cultivation system for technical talents

The implementation of the system for FH education teaching mode is very perfect, from the targets of talents' training, specialties and curricula setup, methods of teaching and evaluation to the cultivation of teachers, which has formed its unique and integrated system, and set up a complete legal protection and comprehensive quality supervision system to ensure the effective operation of the education mode. It is the perfection of its training system that has ensured the quality of the FH graduates, who have been popular in all walks of life in Germany.

\section{The problems of the cultivation of applied talents existing in our country [11]}

At present, the first problem of the cultivation of applied talents existing in our country's local colleges and universities is the disjointing from the employment market. Many local colleges and universities lack their own characteristics of schooling, which is the bigger gap to enterprises' actual employing demands. Among those graduates, there are not only few qualified blue-collar talents to do basic work, but also few qualified top applied talents to engage in technical and managing work. Because the cultivation mode of applied talents in local colleges and universities is very simple, the phenomenon of stereotyped graduates from these colleges and universities is serious, which has 
resulted in the disjointing of cultivation of engineering talents from the employment market in local colleges and universities, thus it is difficult to adapt to the demands of employment market . The second problem is that professional courses lack the latest development of times, science and technology, what makes things worse is that these courses lack the characteristics of their locality. Current professional courses of local colleges and universities in our country basically copy the professional courses of some research universities, not only do they teach their students the same contents, but also adopt similar teaching methods. More often than not, they teach the professional courses according to the teaching plan, adopting the traditional force-feeding teaching methods. Because their training target and direction is not clear, it is difficult to form their distinct characteristics of talent cultivation system. Moreover, the teaching plan is lack of flexibility. Each technology has been developing rapidly, so the cultivation of applied talents should emphasize more on knowledge updating, local characteristics, only by adopting more flexible teaching plans, can we cultivate popular practical talents to serve the local economic construction better. The third problem is the curricula mainly focus on professional theory courses and neglect the cultivation of students' practical abilities in these application-oriented universities, therefore it is difficult to cultivate applied talents with innovating abilities. The fourth problem is the construction of teachers' team is backward, and there is a big gap between the professional ability structure of the teachers in local colleges and universities and the requirements of employers. A large number of teachers are short of practical experience, and do not have the practical research and development abilities.

\section{The enlightenment of German FH education to the cultivation of applied talents for our country}

With the rapid development of local economy, local colleges and universities keep in close contact with local social and economic development, and one of the main tasks local colleges and universities face with is to satisfy the higher requirements for the training of applied talents put forward by local government organs, enterprises and institutions. In the new situation, each college and university of applied sciences must effectively take up the tasks of cultivation of local advanced applied talents, scientific and technological innovation and social service .Take computer department for example, we must draw on the experience of German FH actively, change the ideas of education, strengthen the teaching reform and innovation of professional education. Concrete measures are as follows :

Establish a perfect training system of applied talents

From the training target of applied talents, arrangements of specialties and curricula, teaching mode, evaluation method, to the cultivation of teachers, we should form a complete set of talent cultivation system, and set up the comprehensive quality supervision system to ensure that the education model operates on effectively. As for the arrangements of specialties, we should give priority to application, emphasize the combination of theory with practice, which has the specific industry characteristics.

Training practical talents with the combined efforts both from enterprises and universities

At present, China's local colleges and universities have noticed the importance of cooperation of enterprises, universities and research institutes to cultivate talents and put it into practice to the implementation to different extent, but in view of various factors, in the concrete implementation process, there still exists the problem of separation between production and universities, and the problem that the learning is not related to practice. We can use the experience of $\mathrm{FH}$, keep close contact with society and enterprises .

Construction of experienced teachers' team of technological practice

In order to guarantee the students' practice ability training, the cultivation of technologically applied talents cannot go without the teachers' team who not only know theoretical knowledge, but also have a good command of rich practical experience. In this respect, German FH undoubtedly has set an example for us. To establish double-quality teachers' team is the development targets for colleges and universities of applied science. Three specific aspects are as follows: First, actively introduce double-quality talents whose teaching level is high and practice ability is strong to the 
teachers' team. Second, invite part-time teachers, mainly experts, senior technicians from enterprises, etc., in order to solve the existing problem of the shortage of practical experience among teachers. Third, carry on the practice training program for the existing teachers, and determine their qualifications for teaching posts through the assessment.

\section{Conclusion}

German FH always adheres to the strict concept of high quality in their education process, and implements the cultivation of applied talents in each teaching link. Their advanced education development concept, scientific structure of specialties and courses, practice training as the core of their education system and the strict requirements for teachers, quality monitoring and students' admission qualifications and so on all embody the scientific cultivation of high quality of practical talents. German FH education success has provided valuable experience of the development of vocational education for countries all over the world, especially when local colleges and universities of applied science in our country are in their initial stage of development for connotation construction; it is significant for us to explore the German FH education development mode actively.

\section{Acknowledgment}

Thanks are due to Professor Liu Jin-ling for his assistance in writing this essay.

\section{References}

[1] Shu Guang-wei. The Characteristics and Enlightenment of the Cultivation of Advanced Applied Talents of German FH [J]. Global Education Outlook, 2005, 34 (3): 72-75.

[2] Zhang Cui-qin. Research on German Universities of Applied Science and Technology (FH) [D] Chongqing: Southwest University, Thesis of Master's Degree , 2008.

[3] Shao Ai-jie, Shi Xin-long. German Higher Vocational Training Mode and Its Enlightenment to Our Country [J]. J Overseas Vocational Education, 2005 (10): 59-61.

[4] Huang Ya-ni. Analysis of Characteristics of German FH Practice Teaching Mode [J].Journal of Vocational and Technical Education, 2004 (25): 67-69.

[5] Li Jian-qiu . German FH: Scientific Teaching for Professional Practice [J]. Journal of Comparative Education Research, 2004 (2): 86-90.

[6] $\mathrm{Xu} \mathrm{Li-qin} \mathrm{.} \mathrm{Present} \mathrm{Situation} \mathrm{and} \mathrm{Development:} \mathrm{Comparative} \mathrm{Study} \mathrm{of} \mathrm{the} \mathrm{Cultivation} \mathrm{of}$ Applied Talents between Sino-German Universities of Applied Science and Technology [M]. Hangzhou: [1] Zhejiang University Press, 2008:74-75 .

[7] ZhangJi-ming. Research on Quality Guarantee System of German Higher Vocational Education [J]. Oil Education Bimonthly, 2006 (5): 75-78 .

[8] Comparison between FH and Uni [DB/OL]. http://goabroed.sohu.eon "2004/053 l / 02 / article2033020l, HTML, 2007-8-26.

[9] Zhang Qing-jiu. Comparative Study between German Universities of Applied Science and Technology and Universities of Applied Sciences in Our Country [J]. J Heilongjiang Higher Education Research, 2004 (8): 31-33 .

[10] Chen Yong-ming. Comparisons between International Education Funds [M], Tianjin: Tianjin Education Press, 2006:87-88.

[11] Wang Wei-xian. Strategies of the Cultivation of Computer Talents at College [J]. Chinese Talents, 2011, 14 (7): 225-226. 